\title{
Effect of Chlorhexidine and Fluoride Varnishes on Streptococcus mutans Count and Dental Plaque Index
}

\section{Efeito dos Vernizes de Clorexidina e Flúor na Contagem de Streptococcus mutans e no Índice de Placa Dentária}

\author{
Fernando Yamamoto Chiba*a; Cléa Adas Saliba Garbina; Tânia Adas Salibaa; Artênio José Ísper Garbinª \\ Suzely Adas Saliba Moimaz
}

aão Paulo State University, School of Dentistry, Araçatuba, Department of Child and Social Dentistry, SP, Brazil.

*Email: fernando.chiba@unesp.br

Recebido em: 01/07/2019; Aprovado em: 05/12/2019

\begin{abstract}
The control of dental plaque by chemical means can be a valuable auxiliary resource for individuals who have difficulties in performing dental plaque control through regular oral hygiene procedures. The aim of this study was to evaluate the effect of chlorhexidine and fluorine varnishes on the levels of Streptococcus mutans (S. mutans) present in the dental biofilm and on the dental plaque index. The study was carried out in a sample comprised thirty-nine schoolchildren between 13 and 15 years of age, distributed into 2 groups. Group I received a single layer of varnish with chlorhexidine and thymol on the maxillary right first molar. Group II received the application of varnish with fluoride following the same methodology. S. mutans count and dental plaque index recording were performed 7 days before the application and 7, 15 and 30 days after the treatment. It was observed that chlorhexidine and fluoride varnishes significantly reduced the number of $S$. mutans in dental plaque for 30 days $(p<0.05)$. There was no difference between the varnishes. With regard to the dental plaque index, there was no alteration in any of the experimental time periods for both groups. It was concluded that varnishes, mainly those that contain fluoride, can be an interesting alternative for the prevention of dental caries in collective oral health programs.
\end{abstract}

Keywords: Chlorhexidine. Fluorides. Dental Plaque.

\section{Resumo}

O controle da placa dental por meios químicos pode ser um valioso recurso auxiliar para indivíduos que apresentam dificuldades em realizar o controle da placa dental por meio de procedimentos regulares de higiene bucal. O objetivo neste estudo foi avaliar o efeito dos vernizes de clorexidina e de fúor sobre os niveis de Streptococcus mutans (S. mutans) presentes no biofilme dental e sobre o índice de placa dental. O estudo foi realizado em uma amostra composta por 39 escolares, entre 13 e 15 anos de idade, distribuidos em 2 grupos. O grupo I recebeu uma única aplicação de verniz com clorexidina e timol no primeiro molar superior direito. O grupo II recebeu a aplicação de verniz com flúor seguindo a mesma metodologia. A contagem de S. mutans e o indice de placa dental foram registrados 7 dias antes da aplicação e 7, 15 e 30 dias após o tratamento. Observou-se que os vernizes de clorexidina e flúor reduziram significativamente o número de S. mutans na placa dental por 30 dias $(p<0,05)$. Não houve diferença entre os vernizes. Com relação ao índice de placa dental, não houve alteração em nenhum dos periodos experimentais para ambos os grupos. Concluiu-se que os vernizes, principalmente aqueles que contêm flúor, podem ser uma alternativa interessante para a prevenção da cárie dentária em programas coletivos de saúde bucal.

Palavras-chave: Clorexidina. Fluoretos. Placa Dentária.

\section{Introduction}

A considerable part of the population have difficulties to properly remove dental plaque from all dental surfaces by means of regular oral hygiene procedures because of the lack of ability or motivation. ${ }^{1}$ Hence, dental plaque control by chemical means can be a valuable adjunctive resource for mechanical methods. ${ }^{1-3}$ Among the most used chemical agents, fluoride and chlorhexidine are the ones which have been carefully studied in different ways of application. . $^{48}$

Varnish has been found to be a fast and practical method ${ }^{9,10}$ with good results for a long period of time. ${ }^{11,12}$ Fluoride varnishes are compounds that have special properties such as acting as preventive agents and consequently controlling caries lesions, high concentration of fluoride, as well as longer period of contact between fluoride and dental enamel. ${ }^{11}$ They have high concentration of fluoride, being efficient in dental structure remineralization and are therefore indicated not only in cases of dentinal hypersensitivity but also in the prevention of caries in both adults and children. ${ }^{11,13}$ Varnishes with chlorhexidine, a well known chemotherapeutic agent, used against periodontal-pathogenic bacteria, have been employed as an option in terms of reduction of bacterial activity. ${ }^{10}$ Their indication is based on the properties presented by chlorhexidine to inhibit dental plaque formation as well bactericidal and bacteriostatic actions. ${ }^{8,14}$

In Brazil, there is not a tradition in making use of varnishes and there is the need of further studies that would take into account the local conditions and also the viability of their use, mainly in collective oral health programs. 
This study aimed to evaluate the effect of chlorhexidine and fluorine varnishes on the levels of $S$. mutans present in the dental biofilm and on the dental plaque index.

\section{Material and Methods}

\subsection{Participants}

Thirty-nine schoolchildren (Araçatuba/SP, Brazil), 13-15 years old, were selected for $S$. mutans count in bacterial plaque throug a dental plaque index. Those patients had MS count $\geq 10^{5} \mathrm{CFU} / \mathrm{ml}$ of plaque (colony forming units per milliliter of dental plaque). The study was approved by the Committe of ethics in research of São Paulo State University - Unesp, Araçatuba School of Dentistry (Process number 2000/0943). All participants' responsible signed an informed consent.

\subsection{Study design}

The present study included 39 schoolchildren who presented the maxillary right first molar free of caries, stains, calculi and restorations. The children were divided into 2 groups: Group I $(n=19)$ received a single layer of varnish with $1 \%$ chlorhexidine and thymol (Cervitec, Vivadent Ets. Schann/Liechteinstein), and Group II ( $n=20)$ received varnish with $2.26 \%$ fluoride, Duraphat (A. Nattermann \& Cie. GmbH, Inpharma $\mathrm{GnbH})$. The varnishes were used according to the manufacturers' recommendations. The treatment was performed with a single application of the varnishes only on the vestibular and lingual surfaces of the maxillary right first molar.

The Ainamo e Bay index ${ }^{15}$ was used $(0=$ without bleeding on probing and without dental plaque; $1=$ with bleeding on probing and with dental plaque. Probing was accomplished with a \#5 explorer (Golgran $\AA$ ) in four dental surfaces (mesiobuccal, distobucal, mesiolingual, distolingual) in order to evaluate the dental plaque amount by means of probing and visualization of the area adjacent to the gingival margin.

\subsection{Dental plaque samples}

Dental plaque samples were collected with a sterile curette along the supragingival margin of the tooth surfaces. Dental plaque collection was performed through rubbing a number 5 explorer onto the surface towards a single direction, touching the instrument tip on the area adjacent to the free gingival margin of the buccal and lingual surfaces of the maxillary right first molar.

\subsection{Varnish application}

Firstly, teeth were professionally cleaned and before varnish application, each tooth was isolated with cotton rolls and dried. The varnishes were the applied upon all teeth surfaces using a small brush supplied by the manufacturer. The patients were instructed to avoid eating for $3 \mathrm{~h}$ and brushing their teeth for 24 hours, following the manufacturer's instructions.
Dental plaque samples collection and recording of dental plaque index were performed 7 days before and 7, 15 and 30 days after varnish application.

\subsection{Bacteriological procedures}

Samples collected in dental plaque were kept in thioglycolate solution, at low temperature, form the beginning of sample collection until they were ultimately processed. The culture medium selected for S.mutans was Mitis salivarius Bacitracin, which was prepared according to Gold's method. ${ }^{16}$

After drop-shape inoculation, the petri dishes were kept in anaerobiosis in $\mathrm{CO}_{2}(5 \%)$ and $\mathrm{N}_{2}(95 \%)$ atmosphere for 72 hours in a kiln at $35^{\circ} \mathrm{C}$. S.mutans was identified based on colonial morphology and later confirmed with biochemical tests. ${ }^{17}$ The count was expressed as milligram of dental biofilm (CFU/mg dental biofilm).

\subsection{Statistical analysis}

For the statistical analysis regarding $S$. mutans count in dental plaque, date obtained were converted into logarithm, for the accomplishment of the analysis of variance whit parcels subdivided into time periods and " $F$ " test application for the comparison between the groups and along the time, at 0.1 level.

The comparison between $S$. mutans CFU/ml means was carried out in order to verify the differences among the measurements along time periods, though Tukey test, at a 5\% significance level.

Concerning Ainamo e Bay index, data obtained in scores were converted into square root for the accomplishment of the analysis of variance with parcels subdivided into time period, with the application of " $F$ " test for the comparison between the groups and along the time.

\section{Results and Discussion}

\subsection{S. mutans in dental plaque}

The variation result in the $S$. mutans count in dental plaque before, as well as 7, 15 and 30 days after the application of chlorhexidine and fluoride varnishes can be seen in the figure 1. Reductions of $65.03 \%$ and $78.23 \%$ in the $S$. mutans count was observed seven days after the application of chlorhexidine and fluoride varnishes, respectively. Thirty days after the application of both varnishes, the levels of reduction in $\mathrm{S}$. mutans count remained around $60.00 \%$. 
Figure 1 - Average of the Streptococcus mutans count (CFU/ml) in the dental plaque to groups I and II, at different experimental periods.

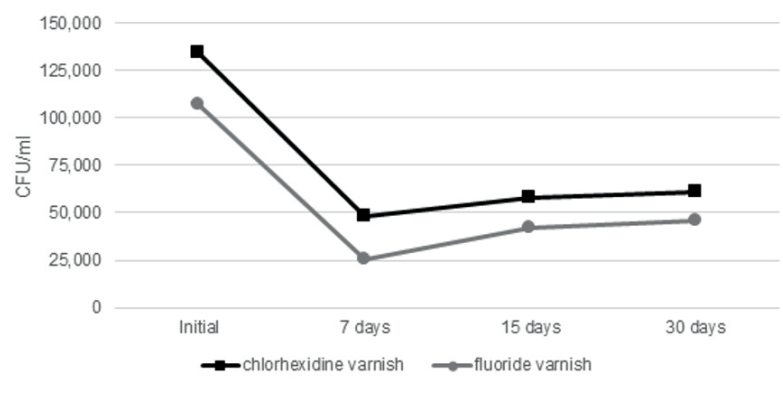

Source: Research data.

Following the analysis of variance of $S$. mutans count, with parcels subdivided into time periods with conversion into logarithm and the application of the " $F$ " test, it was noticed that there was no significant difference between Groups I and II at the different experimental periods of time (Table 1).

Table 1 - Analysis of variance of the Streptococcus mutans count with parcels subdivided into time, conversion into logarithm and application of the F-test.

\begin{tabular}{|l|c|c|c|c|c|}
\hline $\begin{array}{l}\text { Source of } \\
\text { Variation }\end{array}$ & $\begin{array}{c}\text { Degrees of } \\
\text { Freedom }\end{array}$ & $\begin{array}{c}\text { Sum of } \\
\text { Squares }\end{array}$ & $\begin{array}{c}\text { Mean } \\
\text { Square }\end{array}$ & F & p-value \\
\hline Group & 1 & 31.7301 & 31.7301 & 3.6900 & 0.0624 \\
\hline Residue A & 37 & 318.0431 & 8.5957 & & \\
\hline Time & 3 & 43.6705 & 14.5567 & 6.7600 & $0.0004 *$ \\
\hline $\begin{array}{l}\text { Group and } \\
\text { Time }\end{array}$ & 3 & 0.9570 & 0.3190 & 0.1500 & 0.9306 \\
\hline Residue B & 91 & 195.8442 & 2.1521 & & \\
\hline Total & 135 & 572.3576 & & & \\
$*$ * $<0.05$ & \multicolumn{7}{|l|}{} \\
\hline
\end{tabular}

Source: Research data.

When the Tukey test was perfomed, it was possible to verify that the application of both varnishes provides a significant reduction of $S$. mutans $\mathrm{CFU} / \mathrm{ml}$ after 7, 15 and 30 days (Table 2).

Table 2 - Comparison of Streptococcus mutans average count $(\mathrm{CFU} / \mathrm{ml})$ in each experimental period by Tukey test at significance level of $5 \%$

\begin{tabular}{|l|c|c|}
\hline Comparison of Time Periods & Difference & p-value \\
\hline Initial vs 30 days & 65484 & $<0.05$ \\
\hline Initial vs 15 days & 71457 & $<0.05$ \\
\hline Initial vs 7 days & 83271 & $<0.05$ \\
\hline 7 days vs 15 days & -11814 & $>0.05$ \\
\hline 7 days vs 30 days & -17787 & $>0.05$ \\
\hline 15 days vs 30 days & -5974 & $>0.05$ \\
\hline
\end{tabular}

Source: Research data.

\subsection{Ainamo e Bay index}

Figure 2 shows the result of the variation on the Ainamo e Bay index which was recorded before and 7, 15 and 30 days after the application of varnishes that contained either chlorhexidine or fluoride.
Figure 2 - Variation on the dental plaque index to groups I and II, at different experimental periods.

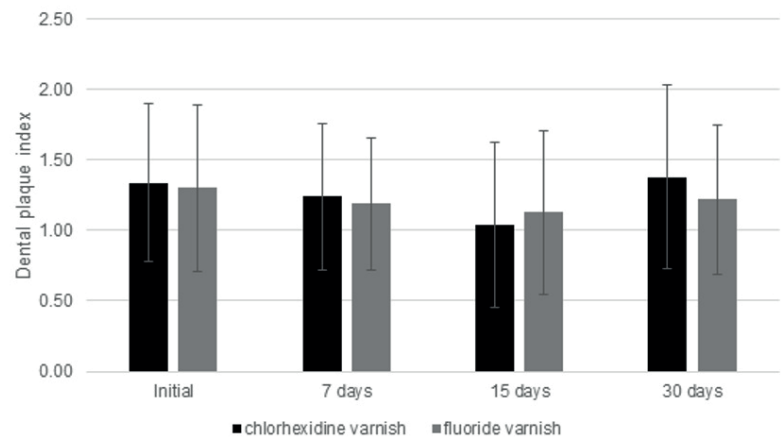

Source: Research data.

According to statistical procedures - analysis of variance with parcels subdivided into time periods, conversion into square root and application of the "F" test - no significant reduction was observed in the dental plaque index in any of the experimental time periods for Groups I and II, and there was no significant difference between the groups in any of the records (Table 3).

Table 3 - Analysis of variance of dental plaque index with parcel subdivided into time, conversion into square root and application of the F-test.

\begin{tabular}{|l|c|c|c|c|c|}
\hline $\begin{array}{l}\text { Source of } \\
\text { Variation }\end{array}$ & $\begin{array}{c}\text { Degrees } \\
\text { of } \\
\text { Freedom }\end{array}$ & $\begin{array}{c}\text { Sum of } \\
\text { squares }\end{array}$ & $\begin{array}{c}\text { Mean } \\
\text { square }\end{array}$ & F & p-value \\
\hline Group & 1 & 0.0859 & 0.0859 & 0.1100 & 0.7378 \\
\hline Residue A & 37 & 27.9639 & 0.7558 & & \\
\hline Time & 3 & 0.4565 & 0.1521 & 1.0000 & 0.3954 \\
\hline $\begin{array}{l}\text { Group and } \\
\text { Time }\end{array}$ & 3 & 0.2810 & 0.0937 & 0.6200 & 0.6057 \\
\hline Residue B & 97 & 14.7302 & 0.1518 & & \\
\hline Total & 141 & 44.0515 & & & \\
\hline
\end{tabular}

Source: Research data.

In order to help decrease the amount of dental plaque, avoiding dental caries and gingivitis, the professional has in his/her hands chemical agents that act as auxiliary instruments of the prevention programs for non-collaborative patients and patients with poor oral hygiene. These chemical agents can be effectively used to decrease the number of microorganisms present in the oral cavity. ${ }^{18}$

Among the most used chemical substances, chlorhexidine and fluoride are found to be quite superior. Both substances act on the control of bacterial colonies, mainly on Streptococcus mutans, providing anticariogenic benefits. ${ }^{19,20}$

Studies carried out to evaluate the antibacterial effect of a chlorhexidine-containing varnish during orthodontic treatment showed an efficient reduction in the number of S. mutans around orthodontic devices. In addition, it was noted that the number of new caries lesions after orthodontic appliance detachment was significantly lower in patients who received chlorhexidine-containing varnish applications. ${ }^{21}$

A field experiment was conducted to evaluate the effects of fluoride varnish treatment on $S$. mutans count in saliva 
among 12-year-old school children. There was significant reduction in the bacteria count when compared with the group that received no treatment suggesting that fluoride varnish can be applied on teeth as an effective agent against $S$. mutans and in caries reduction. ${ }^{19}$ These findings reinforce the results of the present study that showed significant reduction of $S$. mutans (CFU/ml) after application of both varnishes.

In the present study, the application of fluoride varnish was not statically different from the result obtained with the chlorhexidine varnish. This result is in agreement with the study by Baygin et al. ${ }^{22}$ in which were compared the effects of fluoride varnish and a combination of chlorhexidine-thymol varnish on oral hygiene and caries prevention in disabled children. Similar reductions on salivary S. mutans levels were verified one month after treatment with both varnishes. Thus, it is suggested that the treatment with the application of fluoride and chlorhexidine varnishes can be considered a valuable preventive resource, aiming to reduce the need for future restorative treatments. ${ }^{22}$

On the other hand, Ekenback et al. ${ }^{23}$ found a reduction in cariogenic bacteria on radicular surfaces with the use of a fluoride varnish only one week after its application. After 1 month and 6 months, there was no significant effect anymore. Zickert and Emilson ${ }^{24}$ found that topical application of a fluoride-containing varnish had no significant effect on the dental plaque and salivary levels of $S$. mutans in schoolchildren at 4,10 , and 21 days after treatment with fluoride varnish.

In the present study, $20 \%$ of the participants did not show a reduction in the number of $S$. mutans following the application of chlorhexidine-containing varnish. No alteration in $S$. mutans count after treatment with chlorhexidinecontaining varnish was also demonstrated in other studies. ${ }^{25,26}$ The authors considered that the most probable causes of the results can be the early loss of varnish and comparatively large standard deviations.

In the study by Ribeiro et al. ${ }^{27}$ the effect of different types of application of $1 \%$ chlorhexidine varnish on the levels of MS in saliva and dental plaque was evaluated. Three types of application were tested: single application; once-a-day application, on 3 consecutive days; 3 applications with an interval of 4 days in between. The $S$. mutans suppression was fast and short-lasting after intensive treatment for 1 week. No difference could be observed among the diferent treatments.

It is important to emphasize that there are divergences among the results of several studies, probably due to the multiple factors involved and to methodological differences such as different concentrations, frequency of applications, exposure time or varnish remnant and number of treated teeth.

Few studies have been carried out to evaluate the effects of fluoride and chlorhexidine varnishes on clinical variables such as dental plaque index. Similarly to the findings of the present study, Amorim et al. ${ }^{28}$ showed that fluoride varnish and chlorhexidine varnish applications in preschool children with 3-5 years did not promote statistically significant difference in the visible dental plaque index after 1 month. Weiger et al. ${ }^{29}$ also observed that local dental plaque accumulation is not affected by the application of chlorhexidine varnishes, however there is a redution in the microbial vitality. The authors suggest that the chlorhexidine released during and the varnish application causes a partial inhibition of proliferation or lead to a slower proliferation, or even to the bacteria death. Thus, varnish can be considered as a means of topical application that shows many advantages such as easy application, safe method, possibility to treat specific site, acceptability of the product and demands few annual applications. ${ }^{30}$

\section{Conclusion}

Based on the results of the present study, it was possible to conclude that both varnishes caused a significant redution in the number of $S$. mutans in dental biofilm with one application on a specific site for a period up to 30 days, but they did not cause a reduction in the dental plaque index evaluated 7 days after the application.

\section{References}

1. Rode SM, Gimenez X, Montoya VC, Gómez M, Blanc SL, Medina M, Salinas E, et al. Daily biofilm control and oral health: consensus on the epidemiological challenge-Latin American Advisory Panel. Braz Oral Res 2012;26 Suppl 1:133-43. doi: 10.1590/S1806-83242012000700020

2. Sharma M, Pandit IK, Srivastava N, Gugnani N, Gupta M. A comparative evaluation of efficacy of Streptococcus mutans counts in saliva: an in vivo study. Int J Clin Pediatr Dent 2018;11(2):94-9. doi: 10.5005/jp-journals-10005-1492.

3. Sudhanthar S, Lapinski J, Turner J, Gold J, Sigal Y, Thakur $\mathrm{K}$, et al. Improving oral health through dental fluoride varnish application in a primary care paediatric practice. BMJ Open Qual 2019;8(2):e000589. doi: 10.1136/bmjoq-2018-000589.

4. O’Mullane DM, Baez RJ, Jones S, Lennon MA, Petersen PE, Rugg-Gunn AJ, et al. Fluoride and oral health. Community Dent Health 2016;33(2):69-99. doi: 10.1922/ CDH_3707O'Mullane31.

5. Scherrer CR, Naavaal S. Cost-Savings of Fluoride Varnish Application in Primary Care for Medicaid-Enrolled Children in Virginia. J Pediatr 2019; pii: S0022-3476(19)30592-X. doi: 10.1016/j.jpeds.2019.05.026.

6. Ben Khadra GM, Arrag EA, Alammori M, AlKadi MF. The effect of chlorhexidine-thymol and fluoride varnishes on the levels of Streptococcus mutans in saliva in children aged 6-8 years. Indian J Dent Res 2019;30(1):67-72. doi: 10.4103/ijdr. IJDR_208_17.

7. Figuero E, Nóbrega DF, García-Gargallo M, Tenuta LM, Herrera D, Carvalho JC. Mechanical and chemical plaque control in the simultaneous management of gingivitis and caries: a systematic review. J Clin Periodontol 2017;44 Suppl 18:S116-S134. doi: 10.1111/jcpe.12674.

8. Balagopal S, Arjunkumar R. Chlorhexidine: The gold standard antiplaque agent. Pharm Sci \& Res 2013;12:270274.

9. Carvalho DM, Salazar M, Oliveira BH, Coutinho ES. Fluoride varnishes and decrease in caries incidence in preschool children: a systematic review. Rev Bras Epidemiol 2010;13(1):139-49. doi: 10.1590/S1415- 


\section{$790 \times 2010000100013$}

10. Naidu S, Tandon S, Nayak R, Ratnanag PV, Prajapati D, Kamath N. Efficacy of concomitant therapy with fluoride and chlorhexidine varnish on remineralization of incipient lesions in young children. Int J Clin Pediatr Dent 2016;9(4):296-302. doi: 10.5005/jp-journals-10005-1381.

11. Mishra P, Fareed N, Battur H, Khanagar S, Bhat MA, Palaniswamy J. Role of fluoride varnish in preventing early childhood caries: A systematic review. Dent Res J (Isfahan) 2017;14(3):169-76. doi: 10.4103/1735-3327.208766.

12. Arruda AO, Senthamarai Kannan R, Inglehart MR, Rezende CT, Sohn W. Effect of 5\% fluoride varnish application on caries among school children in rural Brazil: a randomized controlled trial. Community Dent Oral Epidemiol 2012;40(3):267-76. doi: 10.1111/j.1600-0528.2011.00656.x.

13. Petersson LG. The role of fluoride in the preventive management of dentin hypersensitivity and root caries. Clinical Oral Investigations 2013;17(Suppl 1):63-71. doi: 10.1007/s00784-012-0916-9.

14. Slot DE, Vaandrager NC, Van Loveren C, Van Palenstein Helderman WH, Van der Weijden GA. The effect of chlorhexidine varnish on root caries: a systematic review. Caries Res 2011;45(2):162-73. doi: 10.1159/000327374.

15. Ainamo J, Bay I. Problems and proposals for recording gingivitis and plaque. Int Dent J 1975;25:229-35.

16. Gold OG, Jordan HV, Van Houte J. A selective medium for Streptococcus mutans. Arch Oral Biol 1973;18(11):1357-64.

17. Van Rijkom HM, Truin GJ, vant't Hof MA. A metaanalysis of clinical atudies on the caries-inibiting effect of cholorhexidine treatment. J Dent Res 1996;5:790-5. doi: $10.1177 / 00220345960750020901$.

18. Tyski S, Bocian E, Mikucka A, Grzybowska W. Antibacterial activity of selected commercial products for mouth washing and disinfection, assessed in accordance with PN-EN 1040. Med Sci Monit 2013;19:458-66. doi: 10.12659/MSM.883952.

19. Badjatia S, Badjatia RG, Thanveer K, Krishnan ACG. Effects of fluoride varnish on Streptococcus mutans count in saliva. Int J Clin Pediatr Dent 2017;10(1):62-6. doi: 10.5005/jpjournals-10005-1409.

20. George AM, Kalangi SK, Vasudevan M, Krishnaswamy NR. Chlorhexidine varnishes effectively inhibit Porphyromonas gingivalis and Streptococcus mutans: an in vivo study. J Indian Soc Periodontol 2010;14(3):178-80. doi: 10.4103/0972-
124X.75913.

21. Okada EM, Ribeiro LN, Stuani MB, Borsatto MC, Fidalgo TK, Paula-Silva FW, et al. Effects of chlorhexidine varnish on caries during orthodontic treatment: a systematic review and meta-analysis. Braz Oral Res 2016;30(1):e115. doi: 10.1590/1807-3107BOR-2016.vol30.0115.

22. Baygin O, Tuzuner T, Kusgoz A, Senel AC, Tanriver M, Arslan I. Antibacterial effects of fluoride varnish compared with chlorhexidine plus fluoride in disabled children. Oral Health Prev Dent 2014;12(4):373-82. doi: 10.3290/j.ohpd. a32129.

23. Ekenback SB, Linder LE, Lonnies H. Effect of four dental varnishes on the colonization of cariogenic bacteria on exposed sound root surfaces. Caries Res 2000;34(1):70-4. doi: $10.1159 / 000016572$.

24. Zickert I, Emilson CG. Effect of a fluoride-containing varnish on Streptococcus mutans in plaque and saliva. Scand J Dent Res 1982;90(6):423-8.

25. Wallman C, Birkhed D. Effect of chlorhexidine varnish and gel on mutans streptococci in margins of restorations in adults. Caries Res 2002;36(5):360-5. doi: 10.1159/000065957.

26. Sandham JH, Nadeau L, Phillips HI. The effect of chlorhexidine varnish treatment on salivary mutans streptococcal levels in child orthodontic patients. J Dent Res 1992;71:32-5. doi: 10.1177/00220345920710010501.

27. Ribeiro LGM, Hashizume LN, Maltz M. Effect of different $1 \%$ chlorhexidine varnish regimens on levels of mutans streptococci in saliva and dental biofilm. Am J Dent 2008;21:295-9.

28. Amorim RG, Leal SC, Bezerra AC, Amorim FP, Toledo OA. Association of chlorhexidine and fluoride for plaque control and white spot lesion remineralization in primary dentition. Int J Paediatr Dent 2008;18(6):446-51. doi: 10.1111/j.1365263X.2008.00914.x.

29. Weiger R, Friedrich C, Netuschil L, Schlagenhauf U. Effect of chlorhexidine-containing varnish (Cervitec) on microbial vitality and accumulation of supragingival dental plaque in humans. Caries Res 1994;28(4):267-71. doi: $10.1159 / 000261984$.

30. Mohammadi TM, Hajizamani A, Hajizamani HR, Abolghasemi B. Fluoride varnish effect on preventing dental caries in a sample of 3-6 years old children. J Int Oral Health 2015;7(1):30-5. 